\title{
Genio y Figura en la Obra de Alvaro Yunque
}

DeRTenece Alvaro Yunque a la generación que, después de la 1. primera guerra mundial, pretendió trastornar los cimientos de un orden civilizado que se aniquilaba en contiendas sangrientas. Testigos de aquella catástrofe - que comenzó a principios del siglo y desde entonces encuéntrase en pleno desarrollo, con una leve pausa para secar la pólvora y engrasar los cañones-, una pléyade de escritores, poetas y artistas que descargaron sus armas sobre un principio de civilidad que tan mal coordinara nuestra convivencia. Surgieron después del armisticio, como aluvión, y sentaron las bases de una humanidad nueva que contempla el estado de ánimo en que el mundo se predispone para la paz perpetua.

Durante los veinte años de mero armisticio, legiones de escritores y poetas, a través de sus himnos y ensayos, ofrecieron a la persona humana un porvenir de justicia. i Jamás época alguna en nuestra historia ha revestido mayor interés para la persona! Porque no sólo se trató de estudiar al hombre y, su medio, sino que se han abarcado los problemas económicos y sociales en que descansa la desigualdad social, y de ahí que las doctrinas estéticas desacordes con el fundamento de la sociedad, que esta generación pretendió crear para bien de todos los habitantes de la tierra, fueran acremente criticadas y sometidas a la dura selección del tamiz que el tiempo nuevo imponía. Cuatro lustros de luchas incesantes, en oculta revolución, dejaron, al entrar en una nueva fase de la transformación del mundo, un saldo alentador. El hombre que pudo salir con restos 
de vida de las trincheras tomó parte en aquella sorda lucha en las calles y se identificó con todos los problemas que la afectaban. Parte él mismo de aquel conglomerado, fué miliciano en aquella cruzada de que resultó la abolición del miedo al principio de autoridad, gracia divina de que se sirven los regímenes autocráticos para perpetuarse en el poder y aplastar en servidumbre a las clases más humildes, que antes se avienen al servilismo que a la rebelión, derecho que les da permanencia de eternidad sobre la tierra.

La generación de Alvaro Yunque ha podido captar todas las inquietudes que el movimiento de postguerra europeo sembró a manos, llenas sobre el mundo. Rebosante de ideas nuevas, de un estado de conciencia que destilaba la esencia divina del humanismo por boca de Romain Rolland, la más grande figura de los últimos tiempos, también la juventud americana experimentó la necesidad de romper con ciertas fórmulas y preceptos, incorporándose al renacimiento del mundo que sangra por sus cuatro costados en estertores de agonía. $\mathrm{Y}$ al terciar en esta pelea, debió sacrificar parte de sí misma, porque no se encontraba con materiales suficientes para elaborar planes independientemente de los que trazaban nuestros hermanos europeos. Si en verdad el problema, tomado en general, a todos afectaba igualmente, en el orden particular existían concepciones distintas, y de ahí que surgiera, en ciertos casos, la imitación y el remedo de lo europeo. Lucha tremenda, de guerra en la paz, ha sido la que media en los veinte últimos años. En ella ha tomado parte el noventa por ciento de la población de los países civilizados. Se ha juzgado con los estilos más duros y en críticas acervas, el destino de nuestro mundo moral. Todo ha sido objeto de la crítica, desde el orden social hasta conceptos que parecían más estables. Pero no se ha discutido y luchado por el mero fin de enfrentarse a la civilización y retarla a duelo, sino por un deseo de vivir, de ver la luz del sol y aspirar el oxígeno. $\mathrm{Ha}$ sido una lucha por la existencia, que nuevamente degeneró en guerra total, porque pretende hallar un nivel en la avaricia del mundo socialmente organizado.

Pero si aquí en América han surgido burdas imitaciones y remedos de lo europeo, por otra parte aqui han surgido también figuras de interés relevante por dotes particulares que las sitúan entre los valores más discutidos de esta generación. Verdad que permanece en pie la esclavitud del indio, sobre cuyas espaldas descansa el esplendor de una burguesía ignorante, sin otras luces del destino hu- 
mano que rendir tributo al vicio y a la degeneración más desenfrenada; que tampoco se ha tocado, en génesis, la necesidad de ampliar el radio de acción de la persona que vegeta en el ancestralismo generado por la desigualdad económica; y que no se ha tratado de estudiar concienzudamente fenómenos que dieron base al régimen de comunidad en que vivió el continente bajo la civilización incaica. Todo esto quedó reducido a segundo plano porque la fiebre de la lucha no permitía detenimiento. La vorágine de la vida en estos últimos años exigía lanzazos y mandobles sobre el problema fundamental, desarticulando así el sistema de represión que pesaba sobre el mundo.

Un grito de angustia que venía del tiempo dolorido ha formado un coro que, confundido con el acorde humano derretido en el fuego de los cañones, en lo que debía ser la última guerra entre las personas, llegaba hasta las estrellas. Aquel grito revestía las características de una resurrección del espíritu, y tendía, además, a la reivindicación de la justicia en el ecuménico dolor de la persona humana, que reaparecía ensalzando el triunfo de la idea. $\mathrm{Y}$ a este coro se ha unido la voz firme y vigorosa de Alvaro Yunque, manifestada en $V e r s o s$ de la calle, el libro más completo de la poesía argentina moderna, que tiene acentos de eternidad.

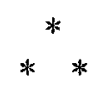

Como lastre literario, tiene Alvaro Yunque todo el pasado de la generación del ochenta, que había luchado infructuosamente contra el romanticismo y los restos de la literatura enfermiza de la Francia decadente. Nacido en la achatada y fría ciudad platense por cuyas aulas pasaron generaciones de estudiantes sin dejar un saldo reconfortante y ni siquiera exprimir los zumos de aquel ciclo intelectual, luego de ciertos escarceos, encontró en Tolstoi un gúa que le llevaría de la mano a través de su carrera; guiaría sus pasos y situariale en la avanzada literaria de su país, como una promesa desgraciadamente malograda después el embanderarle en un sector político autoritario. Alvaro Yunque comenzó hurgando en los restos de aquel movimiento intelectual del que formaban parte Ricardo Gutiérrez, Andrade, Guido Spano y otros enamorados de la Revolución Francesa, representantes típicos de su generación, y jóvenes que constituían 
un grado de integridad dentro del conjunto, tales como Obligado, Coronado y Encina, que exhibían la movilidad de los años en que no se hablaba más que de amores trágicos, de desengaños y de muerte, elementos que fueron dando vida al tango nacional. Pero los poetas mencionados en íltimo término ya discutían sus producciones, y por eso se observa una diferencia fundamental con respecto a los primeros que, Alvaro Yunque estudiaba de pies a cabeza. Con tal acopio de conocimientos va formándose su propio gusto poético. A esa inquietud de entonces responde un artículo de Ernesto Quesada que más tarde iba a tener cierta resonancia, al significar que la juventud leía con pasión a los adalides de 1830, 'de quienes Musset era ídolo y Víctor Hugo, pontífice. En realidad, puede decirse sin equivocación que la tendencia de una parte de la juventud contemporánea de Alvaro Yunque denotaba deseos de conocer; leía mucho, pero casi exclusivamente libros franceses.

Los dos gustos preferidos, el romanticismo y el clasicismo, constituyeron el elemento de la generación del ochenta, que se alimentaba del pasado. E1 viejo romanticismo había encontrado campo propicio que le presentaba como nota de nuevos adalides en materia literaria, al extremo que el propio Alvaro Yunque no pudo sustraerse a escribir un libro de juventud, como de veinte mil versos, que finalmente mereció el destino que era de esperar: la destrucción. Cincuenta años o más habían pasado desde que ese mismo espíritu batallador constituia en la capital francesa el pronunciamiento de rebeldía contra la estrechez académica: habíanse visto caer ya derruídos los muros de aquel templo, ahora reducido a polvo; pero los argentinonos aferrábanse a esa doctrina que había cumplido su misión, volviendo a la línea primitiva de los combates románticos, creyendo que desplegaban con ello banderas de renovación. Alvaro Yunque no permanecía ajeno a los grandes debates que se suscitaban en interés del carácter intelectual. El romanticismo y el clasicismo creaban un ambiente de ardor apasionado que hallaba eco en el espíritu de los argentinos sostenedores del movimiento, pero ellos llegaron hasta vestir sus producciones con el carácter francés: las banderas de renovación que creían desplegar estaban raídas. Sin embargo, ese ciclo literario, que tiene sus características propias como inquietud de un momento, aunque vacío en contenido, sirve de puente a otra generación que aparece inmediatamente después, con expresión, ideas y sentimientos distintos, porque es más real, tiene un horizonte más amplio y está 
más cerca del tiempo, si bien sólo como manifestación de juventud. Esta generación, desde el punto de vista literario, si ciertamente su valor es relativo, imprime a su composición características muy personales y con un sello propio. Ricardo Rojas la llamó "la promesa de la gloria", y en verdad, hubiera marcado un rumbo reconfortante en el ambiente si no feneciera antes de haber cumplido su misión. Por fortuna, Alvaro Yunque ha recogido algunas de sus enseñanzas. La seriedad de sus composiciones y la reciedumbre de su estilo tienen cierta similitud con $M$. García Mérou, último baluarte de aquella generación que supo mantener el fuego sagrado de una juventud toda bríos. Aunque era enemigo de los cenáculos, Yunque adquiere un relieve mucho más interesante cuanto que la obra literaria supone herramienta: el estilo.

Mientras otros discutían, Alvaro Yunque continuaba estudiando el medio en que se desenvolvía: una tragedia desarrollábase en el hombre. Discípulo entonces de Tolstoi, como habíalo sido políticamente antes de los próceres del viejo socialismo político, en vano luchaba por encontrar el verdadero camino que guiaría sus pasos en el futuro, y al analizar su conciencia, pudo encontrar una figura que le hablaba con voz de hermano atormentado y le hacía pensar en la bandera del combate; que el pensamiento humano despierta y se felicita de tan grato hallazgo. Rafael Barret, cuyas páginas rebosantes de fe y poesía saturan el alma de Yunque, le dijo al oído que todo vive y alienta al ser humano; que no es la cruz la que redime, sino la lucha abierta que templa los corazones y otorga derecho de existencia al esclavo. $\mathrm{Y}$ tal entusiasmo y fe puso en estas palabras que surgió un libro pletórico de ideas, que desentrañó ciertos aspectos de la vida del maestro, y que su hermano Juan Guijarro, muerto casi inmediatamente, coronara con otro consagrado exclusivamente a este mismo genio.

Al lado de Barret corresponde situar a Almaftuerte, viejo impertinente, desconforme hasta consigo mismo, que, al igual que Tolstoi, tanta influencia ejercería más adelante en la formación literaria de Alvaro Yunque. Pero Almafuerte no consigue cautivarle, como no le cautiva íntegramente Evaristo Carriego, si en verdad ambos le arrancan estrofas de saber chispeante con aquella destreza y firmeza que le son particulares. Barret y Tolstoi han de ser sus maestros: dos almas libres que se encuentran fundidas en un solo corazón, en pos de un ideal. Aquí parece terminar la tragedia y, entonces, casi 
diré como Olegario V. Andrade: "iArriba! que ya asoma el claro día en que el error y el fanatismo expiren con doliente y confuso clamoreo." Lo cierto es que estamos en presencia de un alma redimida, navegante que parece enfilar la proa de su barco en dirección al futuro. La libertad es su norte y la generación a que pertenece le saluda como un testigo dolorido de la historia, como la figura indiscutida del momento que a través de un período de convalecencia agitada, logró situarse en el propio lugar en que un humanitarista, un rebelde, un hombre de su tiempo debe colocarse: en el terreno de la libertad.

A este período pertenecen una serie de composiciones saturadas de idealismo, que hacen ver en Alvaro Yunque toda una promesa. Algunas de ellas presentan el drama de la humanidad que tiene por escenario la propia historia y por argumento la lucha tenaz por el triunfo de la verdad, de la justicia, de la liberación, prevaleciendo al fin sobre el error, el fanatismo y la mentira. En otras, abundan comparaciones hiperbólicas, alegorías fantásticas, derroche de metáforas felices logradas sin esfuerzo. Por otra parte, no dejan de existir en ellas versos de sonoridad metálica, estrofas enérgicas y breves a modo de sentencias, con acentos fulmíneos y raptos de impetuoso lirismo. Al leerlas, el poeta parece alucinado, mas al estudiarlas seriamente obsérvase en ellas un sedimento cristiano que queda en pequeñas dosis.

Sin embargo, la nota más acentuada que Alvaro Yunque imprime a la obra de este período, que va a definir su carácter de poeta moderno, a tono con su tiempo, estriba en un fondo de lirismo nuevo en que aparece el dolor redimido. Su poesía es transparente y reposada. Una labor seria le impone a su espíritu sin arrebatos, una visión luminosa de la vida, que juzga con criterio filosófico de optimismo en su sencilla concepción. Arrastrado a veces por el ímpetu, trata de escaparse hacia otras modalidades, mas lo heroico de su prosa y la fogosidad del entusiasmo siempre se detienen, y surgen así los motivos más simples, que evoca con destreza desconocida hasta entonces, ya con un dejo de sentimiento helénico, ya con carácter civil, como un reproche a la imperfección de nuestra vida organizada.

Posiblemente esta última nota en la producción de Alvaro Yunque ha pasado inadvertida o no se la ha tenido en cuenta. Original en concebir sus imágenes y en tratar los motivos, es un poeta de talla, que huye del erotismo poético, porque para él la poesía es la verdad 
y no concibe que deba imaginársele como estimulante de bajos instintos. Se sirve del verso para expresar una emoción en todo lo que tiene de elocuencia, cual si en otros terrenos se tratara de una herramienta, de un arado o de un taladro simplemente. En el surco de este mundo imperfecto vacía la esencia de su inspiración ardorosa con descripciones filosóficas de refinado humanitarismo, sin pervertir sus sentimientos.

Líricamente concebidas, estas composiciones presentan una nota singular, ajena a los estilos y modalidades del momento, cuya tonalidad y evocación se admiran por su clara sencillez y particular expresión: es clara, sin desbordamientos ni altisonancias, maciza y segura. Un ritmo permanente y una riqueza pletórica de emociones concebidas con mesura, presentan a un poeta cuya honestidad literaria no es común entre nosotros. Enemigo encarnizado de toda escuela, rompe con las modalidades y las convenciones. No pretende seguir tal o cual rumbo lírico, porque el sometimiento supone esclavitud en cualquier orden vital como abstracto. Traza su propio camino, que sigue impertérrito, y de ahi el carácter tan personal que se perfila en su obra y que significa una revolución literaria.

La aparición de este poeta tuvo la particularidad de desinfectar el ambiente. Su libro Versos de la calle produjo cierto estupor; había caído sobre la ciudad porteña como una bomba. Era la suya una musa ciudadana, bajo cuyos trajes existía un cuerpo rebosante de entusiasmos, que se lanzaba jubilosa a la conquista del mundo con bríos de juventud. Ubicado en el modernismo, sin extremar la nota, el poeta segrega allí efusión lírica en abundancia. Tal vez no se revele como un artífice del verso, pero lo que puede faltarle en perfección está compensado con el gusto, la emotividad y el entusiasmo. Su modestia, que ármoniza todavía con un dejo de misticismo, tradúcese en exuberancia, en claridad y mesura a través de un esfuerzo que culmina en algo único, "algo de lo poco que puede y debe leerse". $\mathrm{El}$ "dolor de los demás, en que se basa la felicidad de los menos, es el postulado de Euclides de su geometría": tal el leit motiv de todo el poema yunquiano, al decir de un reputado escritor.

Alvaro Yunque vino a representar un nuevo gusto en la sensibilidad y en el arte y a dar una forma nueva a la versificación, y los espíritus jóvenes, ávidos de razones y de pensamiento, intérpretes de la verdad, encontraron en él su representante. Probablemente por una razón de persistencia, no haya alcanzado aún esa representa- 
ción, pero lo cierto es que la generación actual no puede hallar mejor testigo de su época que esta figura, reciamente tallada y templada, cuya obra adquiere contornos de eternidad. Angel Samblancat, conciencia insobornable de la literatura ibérica, comentando Versos de. la calle, ha podido reconocer en Yunque un poeta de dotes particularísimas por cuanto "al alivio de la popular miseria endereza ... su endecha, al arrullo de su sensibilidad humana y sobre el orgullo de los poderosos ejercita su aguda vena satírica. ¡ En qué sabios metros, en qué caprichosas formas líricas se hace carne ese amor y ese odio, se materializan y concretan las ideas generosas de Yunque, sería difícil reflejarlo de un modo exacto! Hay aquí la franqueza, la fecundidad, el desgano, el número, el ritmo libre y suelto, el soplo huracanado y anárquico. Toda la gama, como se ve, de colores y matices de la paleta. Todas las notas del pentagrama”.

La obra poética de Alvaro Yunque, con haber sido discutida, no fué estudiada como era de esperarse. Admirador de González Prada, el maestro peruano, logra fijar un nuevo horizonte, literariamente hablando. Como éste, es Yunque un renovador del nuevo verbo poético, una estrella silenciosa que todavía no ha encendido los espacios, pero que "calienta las almas con sus rayos de fuego". ¿Logrará Alvaro Yunque fijar definitivamente su residencia poética donde la ha comenzado? ¿ Podrá él, endosado hoy a una forma de dictadura, romper los ligamentos que atan su inspiración y volcar su verbo a la causa de la libertad que su obra respira y que le garantizó un lugar de preeminencia entre nosotros? ¿ Conseguirá desprenderse de lo transitorio y la grandeza de su alma libre susurrará a sus oídos que el hombre es toda la verdad y sólo él, como persona, acreedor desconocido de todo lo grande que permanece en nosotros y nos concita a entregarle todo lo que humanamente le debemos? El tiempo huye, las ideas se transforman, los sistemas desaparecen para dar paso a otros más acordes con nuestra espiritualidad. El hombre, creado para la verdad, la libertad y la justicia, queda aquí como testigo permanente, como juez de nuestro destino futuro, porque es sentimiento y razón, dualismo augusto, gloria y dolor.

II

Boedo y Florida han sido los polos literarios de la generación de Alvaro Yunque. Corto ha sido el ciclo de gestación y más corta 
todavía su desaparición, pero hasta el presente no se ha manifestado en las juventudes literarias de la Argentina un entusiasmo tan pronunciado por conocer la verdad. Como es natural, todo se ha esfumado; las capillas se han confundido y sólo los nombres prevalecen como un punto. Para estudiar la obra poética de Alvaro Yunque forzosamente debemos asociarla al medio en que se ha desenvuelto, interesantísimo desde todo punto de vista como instante y como expresión revolucionaria. Leónidas Barleta, peleador incansable, cuyos arrestos le llevaron hasta una feria del barrio sud donde vendía papas para demostrar a los cagatintas de Florida que no tenía por qué ruborizarse en realizar este trabajo que otras personas menos cultas hacían, fué quien tuvo juicios más ácidos para su generación. Pedro Herreros, si mal no recordamos, ha dedicado una composición muy hermosa a este arrebato de Barleta, por el mismo Herreros secundado en estas faenas domésticas.

El origen de tal definición arrancó en verdad del viejo diario La Montaña, a quien tanto le debe la literatura argentina. Por aquel entonces, dicha publicación abrió un concurso en el que, aparte de Barleta, tomaron parte Elías Castelnuovo, Roberto Mariano y Pedro Herreros. Algunos de ellos resultaron premiados y tal entusiasmo provocó este hecho en Julio R. Barcos, que en el mismo diario publicó un artículo entusiasta, saludando "a los nuevos" que se interesaban por fin en los problemas del pueblo. ¿Barcos no se equivocó! Casi todos los elementos que figuraban en el concurso, salvo una o dos excepciones; han continuado trabajando con tesón, publicando libro tras libro, no quedándoles mucho tiempo para ir al café a discutir sobre problemas literarios.

Todos ellos conocían el gran caudal emotivo de la literatura rusa, que ha podido orientarles en su vida literaria. La revolución rusa, que presentara al mundo, a través de sus viejos escritores, el gran hallazgo de otro mundo, tuvo la virtud entre nosotros de constituir una unidad de conjunto, pues en toda ella palpitan los defectos y virtudes de 1os pueblos. "La revolución rusa me ha confirmado que los escritores de ese país eran profundamente sinceros, dijo Barleta, y creo que debemos a Rusia las más grandes de las lecciones morales y en literatura le debemos la orientación de nuestras fuerzas intelectuales."

Sin embargo, estos escritores no constituyen un grupo literario propiamente dicho más que por afinidad. Alguien ha manifestado que a ese grupo le faltaba cohesión, cuando lo que ocurría es que no 
reflejaba la característica de las pandillas literarias. No se reunían y casi nunca se veían. Cuando se encontraban era en la Editorial Claridad, en que, con el concurso de estos escritores, Antonio Zamora organizó su negocio de libros. En verdad, Antonio Zamora ha desempeñado cierta función como editor oficial del grupo de Boedo, ediciones de veinte centavos y cuando más cincuenta, todas ellas calientitas como churrascos. Elías Castelnuovo, Leónidas Barleta, Alvaro Yunque, Pedro Herreros, Mario Mariani, Gustavo Ricio -además de Zamora, piloto de la nave-, tal era la comandancia de aquella brigada de milicianos a la que más tarde se sumaron los hermanos Rodolfo y Juan Sebastián Tallón, Luis Emilio Soto, Salas Subirat, Armando Stiro y, ya en su agonía, los poetas Pedro Godoy y Aristóbulo Echegaray.

Qué diferencias fundamentales existen entre Boedo y Florida, nos lo dirán Barleta y Alvaro Yunque: "no nos encontramos cómodos en rebaño, dice Barleta, porque perseguimos los mismos ideales. Cada uno de nosotros piensa con su cabeza y no hay dictadores dirigentes. Con este sistema nos va bien y tenemos suficiente para trabajar." En contraposición, huyendo de la vida real que encarnaba la producción literaria de ese grupo de trabajadores revolucionarios que consideraban "el arte como un consuelo del hombre, vínculo espiritual entre los hombres que aspiran a comprenderse y a perfeccionarse", estaba la otra modalidad que entendía una literatura "viciada y artificiosa, localizada en la calle de las tiendas"... "Los valores absolutos de la literatura argentina, están en camino, agrega Alvaro Yunque. Hasta ahora toda ella está constituída de valores relativos que no pueden parangonarse con las figuras del arte universal. Entre nosotros ocurre el repetido fenómeno de que los escritores, al llegar a la madurez, callan o se malogran, que es lo peor, en una especie de epilepsia que los obliga a fabricar libro tras libro, inferiores a su promisora cosecha juvenil."

Los de Florida forman legión alrededor de Martín Fierro, publicación de aquella modalidad. "Pertenecen todos a la familia de los incomprendidos que pasean sus meditabundas figuras por los salones de arte y se detienen con gestos de insuficiencia ante los escaparates de las librerías. Son jóvenes, pero es como si no lo fueran. Tienen todos los defectos de las generaciones pasadas y contadas virtudes nuevas. Admiran la pintura infantilista de Figari y se desviven por hallar nuevos medios de expresión", y cacarean "como si hubiesen 
descubierto un nuevo continente. Otros, los que tienen ansias de nuevos horizontes - agrega Barleta- importan las funambulerias francesas. $Y$ esto con el criterio muy provinciano del que usa una prenda que estuvo de moda en el viejo mundo hace algunos años". " ¿No podrían esos literatos de Florida orientarse en la literatura de países más sanos que Francia?", pregunta Barleta... "Francia no ha hecho otra cosa que vender frivolidades al mundo. Ni la obra de Anatole France, ni la obra hermosa de Romain Rolland, ni la de tantos otros a quienes veneramos, exime a Francia de esta culpa. Cuando Francia debió callarse, porque no tenía nada que decir, inventó la escuela modernista"... "Los de Boedo son los que escriben sin mayores preocupaciones retóricas porque tienen algo que decir al pueblo, y esto es lo fundamental para ellos; los de Florida son los que escriben y no tienen nada que decir $\mathrm{y}$ hacen juegos malabares con palabras", colocándose fuera de su tiempo y de su época, ajenos a los ajetreos del mundo y su medio, desconocedores de la misión que cada período impone a su juventud en pro de un sentimiento nuevo de la vida. Fuera de su mundo, logran golpear en un bombo roto: "Un arte para unos pocos, un arte para iniciados, con clave, con pequeños misterios y recovecos no puede ser duradero. Los que buscan una etiqueta para sus expresiones artísticas, son los que todavía no han hallado, en arte, su camino. $\mathrm{Y}$ los que ni siquiera están seguros de su vocación y simulan la obra de arte, como cualquier oficio liberal", no ven más que prebendas, consideraciones y vanidades que el arte puede dispensarles.

"Todos somos testigos de la peregrina fortuna de este bastardo que ha ido poco a poco conquistando privanzas en todas las capas sociales. La gente bien vestida de los teatros hace visar los tangos; las niñas desgranan sus notas en los pianos y filtran por sus finas gargantas la jerga del arrabal. Y el pueblo, por las calles y en medio de sus faenas, canturrea tangos como antes cielitos, vidalas y yaravies. Esta es la realidad, mal que nos pese", dice Carmelo M. Bonet, refiriéndose a este ciclo literario: "El éxito de la canción porteña, continúa Bonet, no es un fruto del azar ni del capricho, pues esta canción trasunta un estado de conciencia colectiva; resume la tristeza del suburbio porteño, la tragedia humilde y cotidiana que se esconde en las zahurdas del conventillo y de las casuchas de madera y cinc de los barrios pobres." $\mathrm{Y}$ aquí reside, en su forma, el antagonismo de las modalidades de uno y otro grupo. 
Pero Alvaro Yunque no se conforma con ello, e interviene en la contienda: "para quien crea que el arte literario tiene la seria labor de hacer que el alma humana se supere, la vieja generación de escritores argentinos poco tiene que decirle. En sus mejores hombres y obras se presenta como una invertebrada sucesión de ensayos. Nuestro ambiente hasta ahora fué poco propicio. La política y el periodismo, principalmente, después de la burocracia, han devorado las mejores energías de los hombres que, nacidos en Europa, hubieran dado larga y honda labor de escritores: Sarmiento o Eduardo Wilde o Hernández; Almafuerte o Payró o Gerchunoff. Por fuerza, entonces, los maestros debimos buscárnoslos fuera. ¿Dónde hallar un Tolstoi entre los nuestros? De los nuestros, si lo es, quien ha influído en mí, provocando mi devoción, es Rafael Barret."

"El arte es para todos y a todos beneficia y está en todos, ratifica Barleta." "Cobra una forma actual para la élite del pensamiento y llega a manera de remota influencia hasta las mismas capas de la sociedad humana por impermeables a toda manifestación estética que parezcan; de suerte que el propio patán que modela un cacharro o construye un rancho, o canta o suena un instrumento o ama, lo hace influído y guiado por ancestrales corrientes sentimentales y estéticas, que los artistas legaron al mundo. Por el ojo del artista, la humanidad descubre la belleza. Por obra del artista se ve tentada a poner su alma a tono con la belleza formal que se le descubre. Como tal, el artista no tiene necesidad de poner su obra al servicio de la política: pero sí a disposición de la verdad y de la justicia. El arte no puede ser representación de lo inicuo. i Si se arrodilla a los pies de la dictadura moral, o política, se empequeñece; si se postra ante la injusticia, se envilece, $y$ arte de perversión, de prostitución, no es arte!"

Este movimiento literario, interesantísimo para el porvenir del país, "ha propiciado el desarrollo de un arte sano, verídico, que se identifica con el paisaje y con el hombre" y forma, indiscutiblemente, por "los méritos de la labor realizada, la vanguardia artística del país, título éste que cede generosamente a quienes lo disputen ... De todos modos ha encabezado aquí el único movimiento artístico serio. Y como debía tomar su ubicación, lo hizo, lógicamente, en la izquierda, como no podía ser por menos". A este movimiento, los viejos han contribuído con algo, sin duda: "No les ha faltado talento, dice Alvaro Yunque, les faltó heroísmo, no valor para sobreponerse, aislán- 
dose al medio provinciano, capacidad para renunciar al éxito y al oro que él les brindaba a cambio de sus almas de artistas." Sin embargo, esto no quiere decir que se considere esta generación superior a las anteriores, si bien lo es en número y en acento de rebeldía que trasunta por todos sus poros. Alvaro Yunque reconoce que los de su generación, surgidos de la postguerra, "se han mostrado triviales y arrivistas, indignos del trascendental, espantoso espectáculo que les tocó ver pupilas jóvenes" y confiesa que "toda la poetambre politiquera y sin rumbo cierto" que forma la masa de la actual generación, le "inspira un gran desprecio".

"Mi generación dejará tres o cuatro nombres, quizás de valor relativo." Por el momento no hay que apresurarse. "Cuando el medio esté preparado, surgirán los genios argentinos; pero no quieran hacernos creer a los que somos aptos de pensar por cuenta propia que ya los tenemos o que viven. El indio, el español y su secuela: el gaucho, son el pasado. La grandeza de la literatura argentina está toda en el porvenir", afirma Yunque. Y esta vanguardia de escritores, poetas y artistas que "se caracteriza por su rebeldía, por su solidaridad para con los oprimidos y por la seriedad en el arte", ha rendido sus frutos. Quien estudie con detenimiento la evolución literaria de los últimos cuatro lustros observará, sin duda, qué de notas particulares encierra, qué de humanismo y contenido en responsabilidad. No han quedado en pie muchos de los valores que se lanzaron a las lides literarias con resolución, pero sí lo mejor quedó. El tiempo se ha encargado de pasar por su tamiz la obra de unos y otros. Del grupo de Florida, se salvó Don Segundo Sombra como pieza de valor indiscutible. Del grupo de Boedo, aparte de lo brioso de Barleta y algunas de sus obras de realce, que marcan uñ jalón de méritos positivos, quedan en primera línea de fuego Castelnuovo, que con Tinieblas y Malditos aportó una contribución preciosa a la desinfección del ambiente, y Alvaro Yunque. Si abatidos hoy momentáneamente y encastillados, no cabe duda que significa su labor una obra incompleta, pero con grandes dotes que, particularmente en Yunque, tienda a adquirir contornos de existencia.

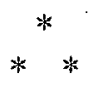

Cabe a Antonio Zamora, editor de esta generación, un lugar excepcional, que ha quedado patente en su modestia, ya que aparte de 
haberle permitido desarrollar su comercio de libros, al extremo de suponer hoy uno de los negocios más prósperos dentro del ramo editorial de la Argentina, señaló con esta contribución una ruta nueva en el ambiente. Su colección Los Nuevos que bautizara con óleos Julio R. Barcos, ha incluído, además de algunos libros de Barleta, A cara o cruz, de Pedro Godoy, espíritu firme y seguro que permanece en su línea, como una figura representativa de aquel ambiente rebelde que se ha inyectado en el asfalto y aún hoy tiene la virtud de constituir motivos de estudio. Una ojeada a la labor de esta generación, desarrollada por una pléyade de escritores y poetas preñados de fe ardiente en donde la metáfora ha afluído a borbotones, con imágenes que tođavía nos enternecen, nos afirma que estamos en presencia de un renacer de la cultura argentina. Las ediciones de veinte y cincuenta centavos que Antonio Zamora lanzara con entusiasmo a la luz pública, desentrañando así los secretos de una nueva inquietud, han dado paso a los libros de alto precio que en estos momentos tienen los libros editados en Buenos Aires, emporio de ediciones castellanas, favorecido por la huída de capitales que, en la Europa esclavizada por la negrura fascista, no encuentran medios adecuados de vida.

Toda esta obra, con ser reducida, nos muestra que todo arte muere cuando se le priva de su genuina fuente de inspiración: la libertad. Sin libertad, vive el hombre entre cadenas o muere frente al piquete de ejecución. Ninguna manifestación de arte se expresa a no ser en muy pequeña escala, sacrificada en honor del vandalismo que la dictadura encarna. Pero si tenemos en cuenta que la pujanza de aquella generación pletórica ha decaído, no por ello, aún hoy, dejaron de significar un problema las mismas ideas que les dieron vida y que adquirieron un lugar de preponderancia entre nosotros. Se entabló un armisticio en la contienda que cuestiones de vida o muerte, impuestas por la guerra total que pesa sobre nosotros, obligaron a dejar pendiente para otra ocasión. Cada uno de los que en ella directa o indirectamente intervinieron sabe perfectamente que la lucha se renueva hasta lograr su definición precisa. Tanto unos como otros permanecen con el ojo avizor, y llegada la oportunidad, cuando el espanto provocado por la barbarie deje a los escritores y poetas tiempo para medir y juzgar sus problemas de estética y los problemas humanos, reaparecerá con iguales bríos.

Un poeta que perdió la voz desde hace algunos años fué Aristóbulo Echegaray; a la inversa, lo continúa siendo, aparte de Godoy, 
por su humildad en crescendo, otro poeta: Antonio A. Gil, que con su Cielo de aljibe nos puso ante los motivos más sencillos, con una dosis tal de humanidad que conmueve. Gustavo Riccio, desaparecido en edad muy temprana, agregó una nota, meritoria por múltiples conceptos, a tono con su tiempo. Hombres de temple, impulsados por una fe, comprendieron que su misión consistía en reivindicar lo poco que del pasado quedara y volcarlo sobre nuestra sensibilidad, para volverlo a la vida. Olvidada de todos la poesía de Almafuerte, Guido Spano, Esteban Echeverria y Andrade, la juventud descarriada se aferró al débil leño del modernismo y otras modalidades en boga que, para sus escarceos literarios y para adquirir un nombre rimbombante, no suponía grandes sacrificios ni obligaba a pensar. E1 ciclo literario que nos ocupa, sin olvidar a Diego Fernández Espiro ni a Evaristo Carriego, que pertenecieron a otra generación, pero que dejaron un lastre que aún hoy llevamos con facilidad, logró dignificar y humanizar nuestras letras dándoles un impulso inigualado por ninguna otra generación en nuestro medio. Las publicaciones periódicas aparecidas en los últimos cuatro lustros, que tratan sobre aspectos literarios, son un documento fehaciente de la importancia adquirida en este orden. Diversos han sido los géneros primordiales que les inspiraron; pero, con ser muchas, todas ellas obedecieron a un plan uniforme de fecundidad.

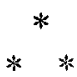

Alvaro Yunque, la figura más interesante de este período, a cuyo alrededor giraba aun sin saberlo el movimiento intelectual de entonces, revestía las trazas de un apostolado que seguía sin desmayos hasta su última consecución. Su obra, que fué madurando con el correr de los años, marcaba las líneas de la revolución literaria que tendría que manifestarse definidamente y encontró un admirador, si de otros quilates, que ofrece una perspectiva interesantísima; hemos querido mencionar a César Tiempo, que, aun cuando apartado de ambos ambientes literarios, por el grado de humanidad que su obra respira y el cúmulo de emociones que trasunta, es acreedor a ingresar en estas milicias literarias. Alvaro Yunque abre su primer libro de versos con una endecha a la "Poesía de la calle, cosa de todos sin dueño; 
yo te aprisiono un segundo, sólo un segundo en mi verso. Poesía de la calle de nuevo; de todos sé y de ninguno, como una ramera, verso!"

Tal la presentación, sin tarjeta ni muleta. Con este prólogo, ya sabemos quién es, qué piensa y adónde va el poeta. La primera y la segunda estrofas ya nos presentan al humano, que se manifestará con ardor a través de los demás libros. Pero el resumen de su libro, en todo su lirismo y emotividad, radica en la "Epístola a Stello, poeta urbano":

Stello: ven conmigo, vámonos por la urbe:

seamos unas horas fibra de muchedumbre.

Hay sol; por esas calles vamos cual dos rentistas que calculan ganancias pasando ante sus fincas; calculemos nosotros, dos poetas urbanos, los versos que la urbe por mes ha de rentarnos. Tú sabes mi secreto de hallar en cada piedra una imagen, y en cada rincón ballar un tema. Stello, ya lo intuyes: la nueva poesía no es arte de bibliófilos, arte es de loca avispa, que avispa es el poeta nuevo; y por esas calles vagando liba sobre las cosas y animales para extraer de todos el zumo que ba de hacerse --ioh, misterios de ritmo!- versos, o sea, mieles (y cual la avispa, Stello, tu punzante aguijón debe hacer que respeten tu obra de volador). Stello: deja al tonto que aún sigue creyendo en faunos, en princesas o en sílfides; Stello, tú cree en lo que miran tus ojos indagantes; cree en esa bonita muchacha que en las calles va dejando una cauda de ensueños; y en la mente de melenudos líricos, en "ángel" se convierte; tú transforma su carne rosada en madrigal (aunque mejor sería transformarle en mamá). Deja que el cursi rime sus "martirios" con "litios"; tú, novísimo, rima pujanza y esperanza, que a Grecia reconstruya o que evoque a Venecia porque no ve hermosura más que en ciudades viejas; tu espiritu a lo viejo que permanezca inmoble, más que todas las ruinas no dice un automóvil?, más que muertos canales, un bulevar no inspira, pletórico de luces, de movimiento y vida? No merece una oda tal construcción de hierro que, cual bizarro púgil, agujerea el cielo? $Y$ no merece un himno la clara luz eléctrica numen de la alegría y núcleo de la fuerza? 
De la urbe moderna se yergue en cada esquina una forma multánime de hermosura novísima: que sepa hallar tu espíritu en el paisaje urbano la euritmia de los techos y el ritmo del asfalto; sólo la calle puede brindarte la sorpresa de regalar tus ojos de artísticas vidrieras; de hallar la emoción mística frente a una roja fábrica y la emoción bucólica sobre una verde plaza. Motocicletas, autos, tranvías... Esos locos de audacia, no te inyectan un frenesí impetuoso? No sientes esa angustia noble de superarte al ver un aeroplano rasgar inmensidades? Tal vez echa de menos los pájaros cantores tu numen apacible?; pues, canta a los gorriones: hay tantos como piedras, brotan de las cornisas, fluyen de mechinales, se alzan de las boñigas; canta al gorrión humilde que, al fin, poeta urbano, alza tu verso sátiras como él chillidos agrios. Quieres lección de orgullo? Mira las chimeneas y cúpulas que tocan de espacio sus cabezas. Vete a una usina: rugen motores, baten émbolos, gritan sirenas...., como rimas de un canto épico. Vete a las estaciones; matrices poderosas que, minuto a minuto, paten locomotoras. Vete al puerto: y el biceps de gigantesca grúa le infunda la serena dinámica a tu pluma. Enseñanzas de fuerza y de tesón lecciones, quieres tomar? Emula los rectos ascensores. Anhelas ver la fragua donde forja el futuro la hermandad de los hombres?: Vete por los suburbios. Anhelas ver tus sueños de utopista febril?: una alborada de oro, vete al tío sin fin. Busca el pristino plasma tu espíritu curioso?, búscalo, no en los templos: en los laboratorios. Indagas el pasado?: Bibliotecas, museos te hablarán sabiamente; no iglesia o cementerio. Y el mal, esa ave loca, que en blancos hospitales, en grises manicomiós o en desoladas cárceles, voraz, se nutre a expensas de la sufriente entraña?: vete a ellos, y gime en la bazofia humana. $\mathrm{Y}$ los mercados y los mataderos: babélicas casas de los horrores y a la vez pintorescas? $Y$ colegios, teatros, of icinas o cines? : vete a observar en ellos cual llora el hombre y ríe. Sí, penetra en la carne de los hombres que pasan: dónde hay mayor tragedia que en el ánima humana? 
Sabes ver, y en el pecho de un empleado encuentras un corazón tallado de innúmeras facetas por el dolor, o acaso tal obrero sencillo te hace ver la tragedia que Shakespeare nunca ha visto. Húndete en las entrañas de los vulgares hombres que por tu lado cruzan, y deja al fin los dioses; ya no nos interesan ni dioses mitológicos ni héroes imposibles. Murió Don Juan Tenorio y Jehová; ya dioses y héroes legendarios sólo se ven en cursis films cinematográficos. No es la urbe, este monstruo policéfalo, un himno de fuerza paradójica, de másculo optimismo? No nos dice la urbe que afirma su parábola. aún titubeante, la evolución bumana?... ¡Oh. Stello, es admirable la urbe, $y$ es magnífica: yo al diapasón palpito de la calle que vibra como una arteria hinchada de sangre roja $y$ joven: conmigo ven, que se haga tu voz de viril bronce; y bebe urbana vida, bebe en su sangre roja, motivo de tu canto, lecciones filosóficas!

La urbe es una hembra lozana, amigo. Siéntete poeta y macho; y ámala por su hermosura fuerte. Fecúndala pensando cómo serán sus hijos: tus versos... O es que acaso los rotos pergaminos de la musa de un siglo XVIII te seducen, como hombre, más que un cuerpo viviente del que fluye cual un aroma, el casto deseo de la carne. el natural deseo de amar y perpetuarte? iPerpetúate, amigo; sé hombre al ser poeta y da tu viril canto, no a una estéril tamera (que esto ya son las musas por todos poseidas, la musa del romántico y del decadentista); da tus canciones a la urbe del siglo $\mathrm{XX}$, como a una hembra hermosa das tu fecundo semen!

¿He aquí a Alvaro Yunque! Este solo poema eterniza a un poeta. El vigor de estilo y la profundidad de pensamiento, así como el ritmo y la exquisita sensibilidad volcada en el poema, son manjares deliciosos de una modalidad nueva. Pero al rebelarse contra el ambiente, arrojándolo sobre las cabezas del medio aunque con él se adjudicó una posición singular, por la originalidad y la frescura que mana, logrando de tal modo su propio elogio y la gloria que le caracteriza, forzosamente iba a encontrarse con la repulsa de incapaces para concebir algo similar. No obstante, la tónica que imponía, por todos los conceptos superada a la producción de poetas que en 
generaciones anteriores y en tal eventualidad discípulos no aventajados cultivaban por cuanto carecían de equilibrio dinámico que trasunta de su lirismo, desparrama tal dosis de savia que muchos le siguieron en arrebatos de emulación, sin que consiguieran interponérsele. Cada verso de Yunque es una metáfora y una imagen que cede su lugar a un pensamiento. Pieza de máquina en función, sólo obedece al fin de vivificar en el alma el sentimiento perdido, a través de otras concepciones acordes con un estado de espiritualidad que se manifiesta en la especie cada período histórico.

La poesía yunquiana puede llamarse única entre nosotros y difícilmente hallará quien posea dotes tan puras en estado de superación. Quienes han seguido de cerca el movimiento intelectual de postguerra, se encuentran ante una poesía originalísima que, si en ritmo aseméjase a la concepción que del verso tenía González Prada, maestro indiscutible, en reciedumbre de pensar le aventaja en cierto modo. Otros hay que, rebuscando en otras fuentes líricas, han podido imprimir ritmos musicales, más acentuados, pero no encontraremos con facilidad una nota emotiva de contenido superior a la que informa la obra poética de Alvaro Yunque, que, por múltiples particularidades, huye de todos los estilos para crearse en estilo propio.

Versos tales como "Frente a la calle rumorosa en donde pródigo el sol dardea”, o "¿Cuán bellos espectáculos, qué vivir divertido; y tú que entre ellos marchas sin reír, pensativo!"; "Mira allí, en aquel corro, dos chiquillos pelean rodeados de hombres que la lucha comentan"; "mira aquí un automóvil ha destrozado un perro y a un caballo maltrata, furibundo, un cochero", pintan sobriamente una escena del suburbio; y éstos, "Alli rueda un ruido y una bocina atruena y allá ruge un confuso murmurio de marea... Esto, amigo filósofo, esto sí es divertido; pero tú nada escuchas, nada ves, i pobre amigo!", pintan a quien nada ve ni siente en la ciudad; y éstos le endilga a un caballo pensativo: "Sí, amigo, convengamos, es un terrible mal ese que, solitario, te lleva a meditar, y es muy duro en el pecho sentir como un dolor que, máquina sensible, palpita un corazón."

Versos de la calle es un temario de encrucijadas y tristezas, arranque lírico de la urbe en que revientan en hermosas melodías el hombre en la multitud, los faroles, el murallón de la penitenciaría, 
"tan monótono, triste y frío cual una hoja de la ley", la parábola del tropezón y "Por ir mirando cosas eternamente nuevas siempre tengo que darme contra las cosas viejas"; donde habla un hombre sobre la razón de su gravedad, el automóvil fugaz, el "noble adoquín: cuán miserable con vos compórtase el destino que, a ser pisado, os condena en una calle cuando, ungido estar podrías por la fama... sobre los hombros de un ministro!"; el oro cálido, sol del estío, a quien recomienda que se eche "sobre estos hombres flacuchos y pequeñitos" y los llene de "ideas, sangre, músculos y amor"; una familia de inmigrantes; el paisaje desde la azotea, el domingo de lluvia; el tacho municipal "que encierra en él la cosa fea que algún político en su cráneo encierra"; el chico lustrabotas; la usina de luz eléctrica por la cual "los monstruos ya no son vórtices de muerte"; las chimeneas de la fábrica en construcción "que yergue a las nubes su loca red de hierros como si fuera una tela de araña: labor como ella del arrojo". Canta a la sonriente violinista del café que, "para alegrar los hartos que no pueden dormir", sólo tristeza provoca con su "música de esclava cuyo deber es sonreír" para traerle una moneda al amo que la observa, hosco; o canta los cables, la imprenta donde hacen libros, y la cloaca que no habla porque si hablase no quedaría "un hombre vivo en la ciudad", pues tales cosas diría "que de asco se iban a asfixiar"; o bien le endilga un dístico a la acción de un desalojo "en la puerta de un inmundo conventillo", cuando no a la luna "pedazo de día olvidado allá en el cielo" que alumbra "los arrabales siempre oscuros y en silencio"; o bien al viento de otoño que "va errabundo por las calles y aceras", y al viejito hebreo que "vende cigarrillos y que ayer tronar pudo del mismo Sinaî; a una boñiga de gorriones, a una maceta de pensamientos bajo la cual pasó "un doctor y, lívido de envidia, avivó el paso, baja la cabeza..."; a un árbol retorcido y seco; a la fábrica "monstruo rojo que ruge" que "por la chimenea de su nariz, arroja un vaho sucio y un negro hollín"; a un melenudo que pasa "tan estirado y tan grave bajo el chambergo y la melena, que hace creer a quien le mira que llevara algo en la cabeza y anduviera haciendo equilibrios para que no se le cayera"... Le dedica una hermosa composición a un tren de inmigrantes y la fecundidad del suburbio, y romances al carrito de los muertos y a la estatua de un general que está meditando "en mármol ya que nunca lo hiciera en vida"; al vendedor de globos que lleva "en lo alto, sostenido por los pies, un racimo de cabezas de bebés", 
a las prohibiciones edilicias, al peón o al despacho de bebidas, al mitin y una oda a un plátano que, dentro de su sencillez, tiene algo de épico. Canta al turco merchachifle, a la mula de la noria, a la luna por los techos, a un señor catedrático, al café del suburbio que devora ideas y vive "de carne proletaria"; a un charco de agua sucia, a una margarita o a un fraile franciscano compuesto por tres bolas: "trasero, cara y vientre"; a los meaderos de mármol, a las pupilas de mujer, al lacayo de "galera relumbrante y galonado levitón", gañán que es "una triste caricatura de señor" y al banco de una plaza "manso animalito en cuatro patas". Del mismo modo y con igual agudeza y sentido humano entona una elegía al cadáver de un triste maturrango de cuya carne se hartan los perros y los gatos voraces, con su "carne sufrida, atormentada!... Carne de proletario!"; o a los niños del arrabal y al señor boticario; a la ramera y al farol encendido en pleno día; al aplauso y a la inmodestia, a los hombres sandwiches, cuya carne hambreada el comercio alquila "por un mendrugo", y al tranvía stubterráneo; al epílogo del carnaval, al empedrado de la calzada, a la mala administración, a un poeta callejero que arroja "sentimientos a las calles para nutrir conciencias con esos frutos bellos"; al mendigo vanidoso, al orador, o un epinicio, a un aeroplano; al tren de carga (un primor entre todas las otras composiciones), a los árboles floridos, a las ventanas de hospital, a los trabajadores "a la galera del salario uncidos". $Y$ se cierra Versos de la calle como pasa una obrera malos olores y casa de alquiler, y un acorazado, el asesino en el Río de la Plata, ya que "las ciudades que beben de sus aguas son buenas; no se ocultan ni enseñan baterías al que llega". Como broche, la desigualdad y el dolor:

\footnotetext{
i Siempre desigualdad! Esta es el hada que rige nuestros ciudadanos días; pero isiempre dolor!: este es el genio presente de continuo en nuestra vida. Dolor, desigualdad: Amos de todos, hijo cruel de madre prostituta, con hambre y llanto hartáis vuestros señores, pan de placer que el mísero fabrica... Hombres, hombres hermanos: vida es dolor, nos dice el pesimista. Nuestra vida es dolor, hermanos hombres: ipero no debe ser dolor la vida!
} 
A Versos de la calle siguieron $N u d o$ corredizo, Poemas gringos y Cobres de dos centavos, que resumen la labor poética de Alvaro Yunque. Estos tres últimos libros, que también editó Antonio Zamora, son una continuación de la fibrosa tónica de este poeta ejemplar. Sus temas son de lo más humilde y en todos ellos prima el alto contenido de aquel ideal, de aquel arranque vigoroso que observamos a través de las estrofas transcritas, pues Alvaro Yunque está volcado en ese su primer libro sugestivo, donde la imagen va ensartada a la sentencia, al pensamiento recio y al gran contenido de dulzura y de rebeldía inagotable que fluye a sus labios y se eleva presurosa, sin esfuerzo, hacia las alturas. "Sal a mirar con tu dolor; pero al escribir, enciérrate con tu imaginación. Que el corazón piense tus versos, que los pula el cerebro. A la emoción, que es una piedra en bruto, polvo de pensamiento, la hace diamante fúlgido." Así nos dice, y obsérvese qué dosis de emoción no pone en sus palabras: "Hermanos antropófagos, hombres del siglo $\mathrm{xx}$, hombres civilizados, gritad: iViva el Progreso! Ya no nos devoramos los unos a los otros nada más que en los sueños. Tú que andas por costumbre con los ojos en alto, que sean tus miradas, hundiéndose en los cielos, luminosas raices que del azul absorban las emociones y los pensamientos. La imagen es el alma de las cosas. $E 1$ poeta es un hombre de aguzados sentidos que la gusta, oye, mira, huele y toca. Jesús de los pequeños dolores de la calle, dice a la muchedumbre que no las ve ni escucha: ¡Dejad que hasta mí lleguen las imágenes! Escuché tu Novena Sinfonia, Beethoven!; y sali por las calles al milagro tan hecho que viera sin asombro manar luz de las piedras o florecer los postes del telégrafo. Escuché tu Novena, Beethoven! y dije: ¡El hombre es bueno! De luz de estrellas, rutilante orgía, él ; oh cielo profundo!, es la quimera: numen del arte y la filosofía. $Y$; oh cielo!, aquí los hombres desdichados, a tus estrellas sus lamentos alzan... Y en tus estrellas quedan olvidados."

Campo Carpio, Buenos Aires. 